\title{
Pengaruh konsumsi suplemen ekstrak kulit manggis (Garcinia mangostana L.) terhadap inflamasi gingiva pada pasien ortodonti cekat (kajian jumlah leukosit cairan sulkus gingiva)
}

\author{
P. Prayitno* dan Anggy Natya Listyaningrum** \\ *Departemen Periodonsia, Fakultas Kedokteran Gigi, Universitas Gadjah Mada, Yogyakarta, Indonesia \\ **Prodi Pendidikan Dokter Gigi, Fakultas Kedokteran Gigi, Universitas Gadjah Mada, Yogyakarta, Indonesia \\ *JI Denta No 1, Sekip Utara, Yogyakarta, Indonesia; e-mail: prayitno.dent@ugm.ac.id
}

Submisi: 26 April 2016; Penerimaan: 26 Juli 2017; Publikasi online: 31 Agustus 2017

\begin{abstract}
ABSTRAK
Pasien pemakai ortodonti cekat memiliki resiko tinggi mengalami inflamasi gingiva. Inflamasi gingiva ditandai dengan meningkatnya jumlah leukosit cairan sulkus gingiva yang menghasilkan sitokin proinflamasi yang mampu merusak jaringan gingiva. Kulit manggis (Garcinia mangostana $L$ ) mengandung xantone yang memiliki sifat antiinflamasi. Tujuan penelitian ini adalah untuk mengetahui pengaruh konsumsi suplemen ekstrak kulit manggis (Garcinia mangostana $L)$ terhadap inflamasi gingiva pada pasien ortodonti cekat dengan kajian jumlah leukosit pada cairan sulkus gingiva. Dua puluh pasien ortodonti cekat dibagi menjadi dua kelompok, 10 subjek pada kelompok kontrol dan 10 subjek pada kelompok perlakuan yang diseleksi berdasarkan kriteria: usia 18-24 tahun, menderita gingivitis ringan hingga sedang, dan menggunakan alat ortodonti cekat pada fase akhir. Subjek pada kedua kelompok dilakukan initial therapy berupa scaling, kemudian subjek pada kelompok perlakuan mengkonsumsi suplemen ekstrak kulit manggis 2 kapsul 3 kali sehari selama 7 hari. Pengambilan sampel cairan sulkus gingiva kedua kelompok dilakukan pada hari ke-0 dan ke-8 pada regio anterior bawah sebanyak 3 sampel cairan sulkus gingiva tiap subjek. Leukosit dilihat dari hasil pewarnaan reagen Turk melalui mikroskop dengan perbesaran 400 kali. Hasil rerata jumlah leukosit dianalisis menggunakan uji Pair T-test dan uji Independent Sample T-test. Hasil penelitian menunjukkan bahwa mengkonsumsi suplemen ekstrak kulit manggis (Garcinia mangostana $L$ ) berpengaruh terhadap penurunan jumlah leukosit cairan sulkus gingiva secara signifikan $(p<0,05)$. Kesimpulan dari penelitian ini adalah konsumsi suplemen ekstrak kulit manggis (Garcinia mangostana $L$ ) berpengaruh secara signifikan terhadap penurunan inflamasi gingiva pada pasien ortodonti cekat dilihat dari penurunan jumlah leukosit cairan sulkus gingivanya.
\end{abstract}

Kata kunci: Garcinia mangostana L; leukosit cairan sulkus gingival; ortodonti cekat

\begin{abstract}
Effect of taking mangosteen peel extract (Garcinia mangostana L.) supplement on gingival inflammation in fixed orthodontic patients (A study of leukocyte count of gingival crevicular fluid). Patients with fixed orthodontic appliances have a high risk of gingival inflammation. Gingival inflammation is characterized by an increase in leukocyte count of gingival crevicular fluid resulting in proinflammatory cytokines that are capable of damaging the gingival tissue. Mangosteen peel (Garcinia mangostana L) contains xantone which has anti-inflammatory properties. The objective of this study was to determine the effect of consuming mangosteen peel extract (Garcinia mangostana L) supplement on gingival inflammation in patients with fixed orthodontic by studying the leukocyte counts of gingival crevicular fluid. Twenty patients with fixed orthodontic appliances were divided into two groups: 10 subjects in the control group and 10 subjects in the treatment group. They were selected based on the following criteria: age 18-24 years, suffering from mild to moderate gingivitis, and using fixed orthodontic appliances in the final phase. The subjects in both groups underwent initial therapy in the form of scaling, then the subjects in the treatment group took 2 capsules of mangosteen peel extract supplements three times a day for seven days. The sampling of gingival crevicular fluid of both groups was taken on day 0 and 8 in the lower anterior region, that is 3 samples of gingival crevicular fluid per subject. Leukocytes were seen from the results of staining with Turk's reagents through microscope with a magnification of 400 times. The average leukocyte counts were analyzed using Pair T-test and Independent Sample T-test. The results showed that taking mangosteen peel extract (Garcinia mangostana L) supplements has significant effect on the decrease in leukocyte counts of gingival crevicular fluids $(p<0.05)$. The conclusion of this study is the consumption of mangosteen peel extract (Garcinia mangostana L) supplement significantly influences the reduction of gingival inflammation in patients with fixed orthodontic appliances, evident from the decline in the leukocyte counts of gingival crevicular fluids.
\end{abstract}

Keywords: Garcinia mangostana L; gingival crevicular fluid leukocytes; fixed orthodontic 


\section{PENDAHULUAN}

Jumlah pasien yang menginginkan perawatan ortodotik cekat untuk memperbaiki penampilan semakin meningkat beberapa tahun terakhir., ${ }^{1,2}$ Tujuan perawatan ortodonti adalah memperbaiki letak gigi dan rahang yang tidak normal sehingga didapatkan estetik yang baik dan fungsi gigi geligi yang stabil. ${ }^{3}$ Perawatan ortodonti cekat dapat menyebabkan kerusakan pada gigi dan jaringan pendukung gigi yang diawali terjadinya inflamasi gingiva, jika kekuatan yang diberikan tidak tepat dan kebersihan rongga mulut kurang terawat. ${ }^{4}$

Sel leukosit dapat ditemukan pada cairan sulkus gingiva yang mengalami inflamasi lebih banyak dibandingkan pada gingiva yang sehat. Leukosit yang ditemukan terdiri dari leukosit polimorfonukler (PMN) sebanyak 95-97\%, limfosit sebanyak 1-2\% dan monosit sebanyak 2-3\%.5 Sel leukosit PMN diketahui selain mempunyai sifat protektif dengan mekanisme perlindungan melawan koloni bakteri plak dalam sulkus gingiva pada tahap awal inflamasi, juga mempunyai sifat destruktif dengan mengeluarkan sitokin proinflamatori seperti TNF- $\alpha$, IL- 1, dan IL-6, protease, dan $\mathrm{PGE}_{2}$ yang dapat memicu destruksi matriks ekstraselular pada gingiva dan menstimulasi terjadinya resorbsi tulang yang dapat merusak jaringan di sekitarnya secara lokal. ${ }^{6,7}$

Keadaan inflamasi gingiva pada pasien ortodonti cekat akan diperparah jika kebersihan mulut pasien tidak baik. Terbentuknya plak terus menerus membuat kondisi gingiva juga mengalami inflamasi secara terus menerus, sehingga jumlah leukosit pada cairan sulkus gingiva menjadi tidak terkontrol dan terjadi respon inflamasi yang berlebihan. Perubahan morfologis pembuluh darah, secara mikroskopis tampak adanya perlekatan neutrofil pada dinding pembuluh darah terjadi dalam 1 minggu setelah terjadinya akumulasi plak. Leukosit mulai meninggalkan pembuluh kapiler dengan menembus dinding pembuluh darah kapiler dan masuk ke dalam cairan sulkus gingiva. Sebelum terjadi kerusakan jaringan periodontal lebih lanjut maka inflamasi gingiva pada pengguna ortodonti cekat harus dikurangi keparahannya selain dengan cara menjaga kesehatan dan kebersihan rongga mulut, dapat juga dilakukan terapi modulasi inang yang bertujuan untuk memblok jalur inflamasi agar tidak terjadi kerusakan jaringan oleh mekanisme respon inflamasi inang. ${ }^{8}$

Selain dengan pengobatan medis biasa, pengobatan alternatif dengan menggunakan bahanbahan herbal kini lebih sering diminati. Salah satu bahan herbal yang marak diteliti yaitu kulit manggis. ${ }^{9}$ Sejak ratusan tahun yang lalu rebusan kulit manggis sudah sering digunakan sebagai ramuan untuk mengobati infeksi, luka, demam, diare, sariawan, dan sembelit. ${ }^{10}$ Ekstrak kulit manggis kini banyak beredar di pasaran sebagai suplemen pemelihara kesehatan. Suplemen berbahan dasar ekstrak kulit manggis (Garcinia mangostana L.) diketahui mengandung zat aktif xantone dengan konsentrasi yang tinggi yang terbukti memiliki efek antiinflamasi yang kuat. ${ }^{11}$ Berdasarkan latar belakang di atas, penelitian ini bertujuan untuk mengetahui pengaruh konsumsi suplemen ekstrak kulit manggis (Garcinia mangostana $L$.) terhadap inflamasi gingiva pada pasien ortodonti cekat dengan kajian jumlah leukosit pada cairan sulkus gingiva.

\section{METODE PENELITIAN}

Penelitian ini merupakan penelitian jenis eksperimental laboratoris. Penelitian ini melibatkan 20 subjek yang dibagi secara acak menjadi dua kelompok, kelompok perlakuan dan kelompok kontrol. Pengambilan sampel cairan sulkus gingiva semua subjek penelitian dilakukan pada hari ke-0 dengan menggunakan micropipette. Satu orang subjek penelitian diambil 3 area sulkus gingiva sehingga akan didapatkan 30 sampel pada kelompok perlakuan dan 30 sampel pada kelompok kontrol. Kemudian sampel cairan sulkus gingiva diencerkan dengan reagen Turk dan sel leukosit diamati melalui mikroskop dengan perbesaran 400 kali pada 4 kotak besar sudut bilik hitung. Selanjutnya dilakukan initial therapy berupa scaling pada kelompok perlakuan dan kelompok kontrol. Kelompok perlakuan akan mengonsumsi suplemen ekstrak kulit manggis sebanyak 3 kali 2 kapsul sehari selama 7 hari berturutturut sedangkan kelompok kontrol tidak mengkonsumsi suplemen. Hari ke-8 kembali dilakukan perhitungan jumlah leukosit cairan sulkus gingiva seperti hari ke-0. Data hari ke-0 dan hari ke-8 masing-masing kelompok dianalisis dengan menggunakan analisis data paired t-test dan penurunan jumlah leukosit cairan sulkus 
gingiva antara kelompok perlakuan dan kelompok kontrol dianalisis dengan menggunakan independent t-test.

\section{HASIL PENELITIAN}

Hasil pengamatan memperlihatkan gambaran sel leukosit yang terlihat berbentuk bulat berwarna keunguan dengan pewarnaan reagen Turk pada mikroskop dengan perbesaran 400 kali. Penampakan sel leukosit dapat dilihat pada Gambar 1.

Leukosit pada sampel cairan sulkus selanjutnya dihitung pada 4 kotak besar sudut bilik hitung. Rerata dan simpangan baku jumlah leukosit cairan sulkus gingiva kedua kelompok ditunjukkan pada Tabel 1 dan Gambar 1.

Hasil penelitian pada Tabel 1 menunjukkan rerata dan simpangan baku jumlah leukosit pada cairan sulkus gingiva kelompok kontrol hari ke-0 sebesar 5830,00 $\pm 811,937 \mathrm{sel} / \mathrm{mm}^{3}$, kemudian pada hari ke- 8 jumlahnya menurun menjadi sebesar $3978,33 \pm 932,524 \mathrm{sel} / \mathrm{mm}^{3}$, sehingga didapat selisih sebesar 1851,67 $\pm 669,468 \mathrm{sel} / \mathrm{mm}^{3}$. Rerata jumlah leukosit pada cairan sulkus gingiva pada kelompok perlakuan hari ke-0 sebesar $5738,33 \pm 943,643$ sel/ $\mathrm{mm}^{3}$, kemudian pada hari ke-8 menurun menjadi sebesar $3061,67 \pm 825,737 \mathrm{sel} / \mathrm{mm}^{3}$, sehingga didapat selisih sebesar $2676,67 \pm 826,369 \mathrm{sel} / \mathrm{mm}^{3}$.

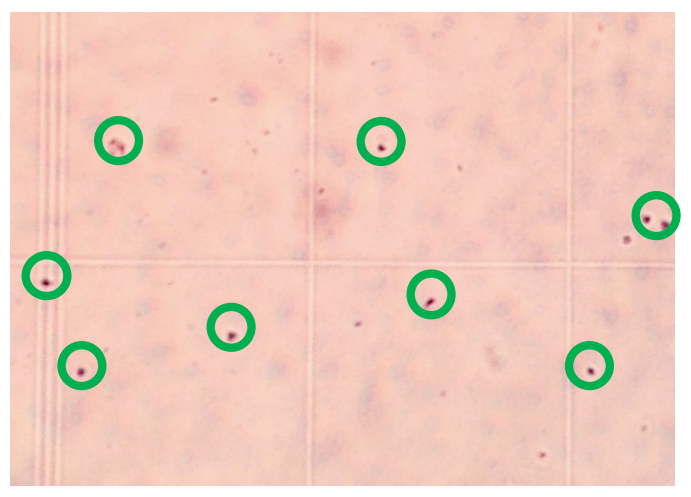

Gambar 1. Sel leukosit (lingkaran hijau) pada cairan sulkus gingiva

\section{Selisih dan simpangan baku jumlah leukosit cairan sulkus gingiva}

Hasil uji normalitas Kolmogorov-Smirnov menunjukkan data kedua kelompok telah terdistribusi normal dengan nilai signifikansi kelompok perlakuan sebesar 0,152 dan nilai signifikansi kelompok kontrol sebesar 0,075 . Hasil uji homogenitas menunjukkan data selisih jumlah leukosit cairan sulkus gingiva adalah homogen dengan signifikansi sebesar 0,442.

Hasil menunjukkan penurunan jumlah leukosit pada cairan sulkus gingiva pada kelompok perlakuan lebih besar dibandingkan kelompok kontrol. Paired t-test dilakukan untuk melihat signifikansi penurunan jumlah leukosit cairan sulkus gingival hari ke-0 dengan hari ke-8 pada kelompok perlakuan dan kelompok kontrol. Independent t-test dilakukan untuk mengetahui signifikansi penurunan jumlah leukosit cairan sulkus gingiva antara kelompok perlakuan dan kelompok kontrol.

Tabel 2. Hasil paired t-test perbedaan rerata jumlah leukosit kelompok perlakuan dan kontrol hari ke 0 dan 8

\begin{tabular}{lcc}
\hline & t hitung & Sig. $^{*}$ \\
\hline Perlakuan & 17,741 & 0,000 \\
Kontrol & 15,149 & 0,000 \\
\hline
\end{tabular}

Keterangan:

*signifikan $(p<0,05)$

Berdasarkan analisis statistik yang tersaji pada Tabel 2, rerata jumlah leukosit cairan sulkus gingiva pada kelompok kontrol dan kelompok perlakuan pada hari ke 0 dan ke 8 mengalami penurunan yang signifikan $(p<0,05)$.

Tabel 3. Hasil independent t-test penurunan jumlah leukosit cairan sulkus gingiva antara kelompok perlakuan dan kelompok kontrol

\begin{tabular}{lcc}
\hline & t hitung & Sig. $^{*}$ \\
\hline $\begin{array}{l}\text { Penurunan Leukosit cairan sulkus } \\
\text { gingiva }\end{array}$ & 4,249 & 0,000 \\
\hline
\end{tabular}

Keterangan:

*signifikan $(p<0,05)$

Tabel 1. Rerata dan simpangan baku jumlah leukosit cairan sulkus gingiva (sel/mm ${ }^{3}$ )

\begin{tabular}{ccccc}
\hline Kelompok & $\mathrm{n}$ & Hari ke-0 & Hari ke-8 & Penurunan \\
\hline Perlakuan & 30 & $5738,33 \pm 943,643$ & $3061,67 \pm 825,737$ & $2676,67 \pm 826,369$ \\
Kontrol & 30 & $5830,00 \pm 811,937$ & $3978,33 \pm 932,524$ & $1851,67 \pm 669,468$ \\
\hline
\end{tabular}


Berdasarkan analisis statistik yang tersaji pada Tabel 3, besar penurunan rerata jumlah leukosit cairan sulkus gingiva antara kelompok perlakuan dan kelompok kontrol menunjukkan perbedaan yang signifikan $(p<0,05)$.

\section{PEMBAHASAN}

Jumlah leukosit pada cairan sulkus gingiva pada kelompok kontrol mengalami penurunan, hal ini karena subjek diberikan initial therapy berupa scaling yang dilakukan untuk menghilangkan plak dan kalkulus sebagai faktor lokal penyebab terjadinya inflamasi gingiva pada pasien yang memakai alat ortodonti cekat. Plak pada pasien ortodonti cekat cenderung lebih mudah terakumulasi meskipun pembersihan mekanis dirasa sudah adekuat. Piranti cekat yang digunakan selama perawatan dapat menyebabkan pembersihan sulit dilakukan, sehingga dengan dihilangkannya faktor lokal melalui prosedur scaling, plak yang terakumulasi dan ekspresi mediator inflamasi yang diinduksi oleh toksin bakteri plak juga akan menurun. Penurunan mediator inflamasi menyebabkan jumlah leukosit cairan sulkus gingiva juga menurun. Keberadaan kalkulus pada lingkungan supragingiva dan sub gingiva merupakan salah satu faktor yang berkontribusi pada retensi plak. ${ }^{12}$ Plak mengandung banyak bakteri yang salah satu produk bakteri tersebut yaitu lipopolisakarida (LPS). LPS kemudian menstimulasi dihasilkannya mediator inflamasi yang dapat meregulasi terjadinya inflamasi gingiva. ${ }^{13}$ Scaling merupakan initial therapy yang bertujuan untuk mengurangi inflamasi gingiva dengan menghilangkan kalkulus dan kontrol plak. ${ }^{14}$ Berkurangnya pertumbuhan bakteri membuat kondisi inflamasi gingiva dapat berkurang yang ditandai dengan penurunan jumlah angka leukosit pada cairan sulkus gingiva. ${ }^{15}$

Sebagaimana kelompok kontrol, pada kelompok perlakuan juga dilakukan initial therapy berupa scaling. Scaling dapat menghilangkan faktor lokal seperti kalkulus dan plak yang terakumulasi, dengan menurunnya kalkulus dan plak maka inflamasi gingiva juga akan menurun yang disertai dengan penurunan jumlah leukosit cairan sulkus gingiva. Aktivitas antiinflamasi yang terjadi pada kelompok perlakuan juga diperoleh dari konsumsi suplemen ekstrak kulit manggis selama 7 hari setelah dilakukannya prosedur scaling. Ekstrak kulit manggis memiliki kandungan antiinflamasi yang mampu menghambat terekspresinya sitokin IL-1, IL-6, TNF- $\alpha$, enzim COX-2 dan produk asam arakhidonat terutama $\mathrm{PGE}_{2}$. Hambatan sintesis sitokin IL-1 pada jaringan gingiva akan memutuskan rantai pensinyalan antar sel inflamasi termasuk sel leukosit berkurang sehingga proses inflamasi gingiva berkurang yang disertai penurunan jumlah leukosit cairan sulkus gingiva. ${ }^{11}$ Terhambatnya ekspresi enzim COX-2 akan mencegah proses pembentukan produk asam arakhidonat seperti $\mathrm{PGE}_{2}{ }^{16} \quad \mathrm{PGE}_{2}$ dan jenis prostaglandin lainnya memicu proses vasodilatasi kapiler yang dapat menyebabkan migrasi sel inflamasi keluar dari vasa darah menuju jaringan. Efek dari penurunan mediator inflamasi ini menyebabkan kondisi vasodilatasi kapiler, peningkatan permeabilitas kapiler menurun yang menyebabkan penurunan migrasi sel leukosit cairan sulkus gingiva. ${ }^{6}$

Menurunnya jumlah leukosit maupun mediator inflamasi selama mengkonsumsi suplemen ekstrak kulit manggis, akan menyebabkan penghambatan proses destruksi jaringan yang disebabkan oleh respon inflamasi inang. Untuk memperkuat upaya pembersihan mekanis plak, agen terapeutik dapat digunakan untuk memodulasi respon inflamasi inang selama perawatan periodontal berlangsung. Terapi modulasi inang dengan agen antiinflamasi bertujuan untuk mengembalikan keseimbangan proses antiinflamasi atau mediator protektif seperti pada individu yang sehat sehingga respon inflamasi yang dihasilkan masih dalam batas normal. ${ }^{12}$

\section{KESIMPULAN}

Konsumsi suplemen ekstrak kulit manggis (Garcinia mangostana $L$.) berpengaruh terhadap penurunan inflamasi gingiva pada pasien ortodonti cekat dilihat dari penurunan jumlah leukosit cairan sulkus gingiva.

\section{UCAPAN TERIMA KASIH}

Terima kasih diucapkan kepada Fakultas Kedokteran Gigi yang telah memberi dana melalui hibah 
penelitian dosen dana masyarakat T.A 2014 dan semua pihak yang telah membantu terlaksananya penelitian ini.

\section{DAFTAR PUSTAKA}

1. Breece GL, Nieberg LG. Motivations for adult orthodontic treatment. JCO. 1986; 20: 166 171.

2. Patrícia GSAO, Tavares RR, Freitas JC. Assessment of motivation, expectations and satisfaction of adult patients submitted to orthodontic treatment. Dental Press J Orthod. 2013; 18(2): $81-7$.

3. Prasad PN, Phull TS, Sharma T. Timing of orthodontic treatment. J Oral Health Comm Dent. 2011; 5(2): 94 - 96.

4. Giannopoulou C. Inflammatory side effects associated with orthodontic tooth movement. Tesis: Faculté de Médecine Université de Genève. 2009.

5. Wilson TG, Kenneth SK. Fundamentals of Periodontics, 2nd ed Quintessene Publishing Co. Inc. Chicago. 2003.

6. Newman MG, Henry HT, Perry RK, Fermin AC. Carranza's Clinical Periodontology, 10th ed. Saunders Elseviers Inc. Missouri; 2006. 213 - 219, $344-340,861$.

7. Reddy S, Prasad MGS, Kaul S, Asutkar H, Bhowmik N, Amudha. Host modulation in periodontics. e-Journal of Dentistry. 2011; 1(3).

8. Yordan B, Prihandini IWS. Efek pasta gigi non detergen pada gingivitis dan stomatitis apthosa pemakai alat cekat. MIKGI. 2003; V(10): $259-261$.
9. Hariyati S. Standardisasi ekstrak tumbuhan obat Indonesia: salah satu tahapan penting dalam pengembangan obat asli Indonesia. Info POM. 2005; 6(4).

10. Warisno K. Kulit Manggis: Hidup Sehat Berkat Sang Ratu yang Berkhasiat. Jakarta: Gramedia Pustaka Utama. 2012.

11. Gutierrez-Orozco F, Failla ML. Biological activities and bioavailability of mangosteen xanthones: a critical review of the current evidence. Nutrients; 2013. 5, $3163-3183$.

12. Axelsson DDS. Diagnosis and risk prediction of peridontal disease. Quintessene Publishing Co. Inc, Slokavia; 2002. 3.

13. Garant PR. Oral cell and tissue. Quitessance Publishing Co, Inc, Illinois, Canada. 2003; 125 $-132$.

14. Newman MG, Takei HH, Carranza FA. Clinical Periodontology, 9th ed., WB Saunders Co, Philadelphia; 2002.

15. Novaes JAB, de Souza SL, Taba MJr, Grisi MF, Suzigan LC, Tunes RS. Control of gingival inflammation in a teenager population using ultrasonic prophylaxis. Braz Dent J. 2004; 15(1): 41 - 45 .

16. Kumar V. Buku ajar pathologi robbins (terj). Jakarta: EGC; 2007. 